\title{
Organizational Innovation: A Review Paper
}

\author{
Ibrahim Bader A. Alharbi', Rossilah Jamil'1, Nik Hasnaa Nik Mahmood², \\ Awaluddin Mohamed Shaharoun ${ }^{3}$ \\ ${ }^{1}$ Azman Hashim International Business School, Universiti Teknologi Malaysia, Kuala Lumpur, Malaysia
${ }^{2}$ Razak Faculty of Technology and Information, Universiti Teknologi Malaysia, Kuala Lumpur, Malaysia
${ }^{3}$ Engineering College, Islamic University of Madinah, KSA
Email: i.bh.taibah@hotmail.com, rosillah@utm.my, nikhasnaa.kl@utm.my, prof.awaluddin@gmail.com
}

How to cite this paper: Alharbi, I.B.A., Jamil, R., Mahmood, N.H.N. and Shaharoun, A.M. (2019) Organizational Innovation: A Review Paper. Open Journal of Business and Management, 7, 1196-1206. https://doi.org/10.4236/ojbm.2019.73084

Received: May 14, 2019

Accepted: July 2, 2019

Published: July 5, 2019

Copyright $\odot 2019$ by author(s) and Scientific Research Publishing Inc. This work is licensed under the Creative Commons Attribution International License (CC BY 4.0).

http://creativecommons.org/licenses/by/4.0/

\begin{abstract}
In recent years, innovation is an important factor for developing organizations in a highly competitive world. Most scholars agree on the positive effect of the innovation on organization, and there are a few studies on the subject. The goal of this paper is to shed light on the definitions, types, importance and how to manage innovation. Through the review of relevant literature, this study intends to deepen our understanding of the theme and provide a comprehensive review of previous research.
\end{abstract}

\section{Keywords}

Innovation, Management Innovation, Administrative Innovation, Organizational Innovation

\section{Introduction}

Innovation plays an important role individually and organizationally on the changing business environment. Innovation is identified as value added to organizational performance and activities [1]. Innovation is developing beneficiaries' value by providing new needs or achieving the existing beneficiaries and market demands in distinct ways [2].

There is an argument that in the contemporary business world concerning organizations, innovation is widely perceived as an important source of competitive leverage in an increasingly fluctuating world [3]. According to the new World Economic Forum report 2018, around 133 million new jobs may provide by 2022, while 75 million jobs are change by technical innovation [4]. Therefore, the McKinsey report shows that $84 \%$ of managers agreed that their future success based on innovation, allows organizations to survive in the competitive 
markets, and contributes to economic growth [5].

As stipulated by a majority of management scholars, innovation capacity remains to be the most pertinent determinant of an organization's performance. A quick search on scholarly articles using "innovation" as the keyword yields tens of thousands of articles. While such articles touch on various conducted studies on organizational innovation, an exploratory search on the different aspects of organizational innovation is prudent. Due to the comprehensive studies regarding organizational innovation, it is wise to explore the existing definitions of innovations, its applications, and advantages from the organizational perspective.

\section{Definitions of Innovation}

In the existing literature that this study has reviewed, varieties of definitions exist for the innovation. This stems from the fact that various stakeholders in organizations perceive innovation in different manners. Despite this, the existing literature confirms the aspect of creativity in organizational innovation. According to [6], the term organizational innovation by large serves to refer to either the creation or the adoption of a notion or behavior that is new to an organization. The keywords in this definition include "idea/behavior" and "new". Organizational innovation emphasizes ideas that are knowledge-based and behavior, which are transformative. Hence innovation looks at how new ideas and behaviors are depicted in a given organization and they serve to positively affect the organization.

In a comprehensive literature review study that delves into organizational innovation as a whole, they explore various definitions of organizational innovation and attempt to merge points from each definition to come up with an increasingly comprehensive description of the term [7]. Accordingly, the multivariate definition of organizational innovation is that innovation pertains; either to the production or the adoption, the assimilation and use of any given value-added novelty in social and economic spheres; the renewal or increase of services, products or even markets; the facilitation of an alternatives techniques of production; and ultimately installing of emergent management system. The definition contends that indeed, innovation can be a process and an outcome at the same time. Such a definition of organizational innovation is indeed quite comprehensive and it touches on various aspects as it pertains innovation. It can be said that innovation is an enhancement of the market, the ideas, the behaviors and other aspects that translate to benefit an organization.

In their comparative study, [8] seems to conform with [6] in brevity and preciseness as it pertains the definition of organizational innovation. According to them; organizational innovation implies the creation and adoption of a notion or behavior thus its effective implementation in the particular organization. They argue that the objective of innovation is to simply come up with business value through the development of worthwhile ideas into a customer-centered 
market. The concept of organizational innovation refers to a mechanism utilized by organizations to adapt to dynamic conditions of technological advancement, competition, and market expansion by creating unique products, systems, and techniques [9]. In essence, organizational innovation is the process by which an organization develops new advanced products or services and its success in introducing those commodities or services to the market. Therefore, it can be defined as an organization's ability to transform ideas and knowledge into new services, processes, or products regularly for the benefit of its stakeholders.

Conclusively speaking, there are various existing definitions of organizational innovation in reported studies. However, it is prudent to note that they all refer to it as one process which is systematic and engages both ideas and behaviors which when enacted can serve to change the organization positively. The definitions of organizational innovation considerably overlap with administrative and management innovation [10]. Table 1 shows a summary of the definitions of organizational innovation.

\section{Types of Innovation}

It is necessary to understand that there are many types of innovation to know the nature of the organization's work [18]. Throughout history, there are many types of innovation explained and reported in the literature. The first author in innovation area was [19], who divided the innovation into particular types including a unique way of production, unique products, new supply chain, new markets, and a new method to manage the business.

Table 1. Summary of organizational innovation definitions.

\begin{tabular}{ll}
\hline Authors & Definitions \\
\hline It is defined as the implementation of a new or borrowed idea internally \\
within the organization that is related to the organization activities such as \\
programs, policies, products services, process, systems, and service that are \\
innovative to the organization.
\end{tabular}


Some researchers such [18] [19] explained that innovation can be achieved through two types which are a product innovation and process innovation. The product innovation relates to introducing new service or unique products. The process innovation relates to developing of new tools and equipment. However, based on [21] they classified the innovation to four types identified as Position, Paradigm, Process, and Products, the position innovation involves the differences in the way of viewed products. The paradigm innovation means the differences in the rational thinking, which reflects into the work. Moreover, [22] classified the innovation into incremental and radical innovation. The incremental innovation is the improvements and changes of the current products or process. While radical innovation is the newness that replaces an existing process and products.

On the other hand, some scholars classified the innovation into administrative and technological innovation [12] [23] [24]. The administrative innovations relate to the change in the organization structure or administrative processes. The administrative innovation develops and implements organization activities such as organizational administrative processes, organizational structure and member's social system within the organization [25] [26]; it includes rules, procedures, management systems, and training programs for members [2] [10] [27]. The technological innovations relate to innovations that result in changes of organizations by adoption the changes in technology by some tools such as new equipment, techniques, processes, methods, and systems. Technological innovation is essential in the technical and it is usually related to technology [28].

Moreover, [24] asserts that administrative innovation causes that organizations come up with innovations to adapt with environmental changes and achieve strategic goals for sustaining and improving performance. Further reviewed technological innovation focus on alternative technological process and products. Therefore, organizations innovate and focus on enhancing productivity, profitability, and boost market share. Table 2 shows a summary of different types of innovation.

\section{Importance of Innovation}

Its notes that initially, innovation has a pertinent function in the economy [35]. Accordingly, the importance of innovation lies in the fact that it can manifest itself in one of the various ways. For instance, innovation is important when there is the introduction or commercialization of either a new or improved product or service as opposed to the current products or services. Thus explains that organizational innovation is indeed crucial as it leads to the emergence of new products and services to the market. On the same note, innovation serves to improve the existing services or products.

Secondly, organizational innovation can serve to come up with an alternative production process or even improve the current business process in the most basic and complex manner. Coming up with a new form of production, or rather 
Table 2. Summary the different types of innovation.

\begin{tabular}{|c|c|}
\hline Authors & Types of innovations \\
\hline Schumpeter [19] & $\begin{array}{l}\text { New products, new production method, new markets, new supply chain } \\
\text { and a new system of organizing business. }\end{array}$ \\
\hline Knight [29] & $\begin{array}{l}\text { Organizational structure innovation, employees' innovation, innovation in } \\
\text { production, process and services. }\end{array}$ \\
\hline $\begin{array}{l}\text { Deward and } \\
\text { Button }[22]\end{array}$ & Radical innovation and incremental innovation. \\
\hline $\begin{array}{l}\text { Tidd and } \\
\text { Bessant }[21]\end{array}$ & $\begin{array}{l}\text { Position innovation, paradigm innovation, products innovation and } \\
\text { process innovation. }\end{array}$ \\
\hline $\begin{array}{l}\text { Daft [12] } \\
\text { Damanpour [23] [24] }\end{array}$ & Administrative and technological innovations. \\
\hline Oke et al. [30] & $\begin{array}{l}\text { Process/service innovation(production, service and administrative), and } \\
\text { Product innovation (incremental or radical innovation). }\end{array}$ \\
\hline $\begin{array}{l}\text { Akgün et al. [31] } \\
\text { Lin [32] }\end{array}$ & Process innovation, product innovation. \\
\hline Rowley et al. [33] & $\begin{array}{l}\text { Process innovation (The organizational structure, management, } \\
\text { administrative, production, technical, and employees innovation), product } \\
\text { innovation (service or product) and position innovation (the systems of } \\
\text { marketing and business). }\end{array}$ \\
\hline $\begin{array}{l}\text { Schmidt and } \\
\text { Rammer [34] }\end{array}$ & $\begin{array}{l}\text { Technological and non-technological innovations. } \\
\text { For technological innovation (marketing and organizational innovation); } \\
\text { for non-technological (process and product). }\end{array}$ \\
\hline
\end{tabular}

a means of production, in this case, implies extreme efficiency as it pertains production and can include reduction of time, increase in production or yielding better products in the same production [36].

Thirdly, organizational innovation is crucial since it can open doors for a new market. This can be perceived as the marketing dimension, and it pertains efforts to ensure that there is smooth marketing of the products. Under this, innovation on the part of the employees, and management alike will translate to better marketing options and yield better sales. Fourthly, organizational innovation can result in the development of alternative supply sources like materials, equipment, and various other inputs. Last but not least, organizational innovation results in fundamental transformations in industrial structures and organizational structure among others. It paves the way for the promotion of employees who are innovative [36].

Organizational innovation improves the creativity and flexibility, which promotes the improvement of technological innovations [37] [38] [39], which provide a justification for the important influences of organizational innovation. Moreover, [17] proved the positive influence of organizational innovation on other different types of innovations was proved, especially on improving organizations' capability to implement new technologies and innovative process. Furthermore, [38] clarified that organizational innovation has a significant influence on firm innovation and competitive advantages, meaning that they afford 
input for innovation capabilities and firm innovation processes.

From an organizational perspective, managers around the world encourage organizational innovation because of the value it can create in their companies. It has been proven that when employees are innovative, there is increased productivity as a result of executing and creating new processes [40]. This has the effect of creating the much-needed differentiation and increases an organization's competitive advantage. In essence, organizations that embrace organizational innovation are able to react more effectively and faster to avert capture and risk opportunities.

The investigation on organizational innovation is still relatively limited but it has kept increasing steadily increasing in the literature [18] [41], and has been identified as a cause of competitive advantage [42] [43].

\section{How to Manage Innovation?}

Innovation is not only just focused on the creation of alternative markets, but it also can avail alternative techniques of serving established and mature markets. Innovation works with emergent technology, and involved in enabling radical opportunities. The importance is about improving old product/technology with the help of using the more current technologies [44]. The issue of innovation in organizations is not new; organizations are braced with the challenge of thinking about changing what they avail to the world and the manner they create and deliver what they offer to continue surviving in a changing market. It was offered a simplified model of innovation, which has four steps [44]. The first step pertains searching for new ideas in the system using $\mathrm{R} \& \mathrm{D}$, and they include regulations, market signals among others. The second step is to select from the set of options; the variants that have high prospects for growth and development. The third step is implementation, and it pertains the conversion of ideas into reality. The last step in the model of innovation is capturing value. This pertains answering the question of how to ascertain that the efforts put across are justified; it can be in either commercial terms or social value. Conclusively speaking; as organizational innovation is perceived as quite important, its management remains to be quite important. Therefore, various models have been offered to dissect organizational innovation using many of theories that including importantly institutional theory, market orientation theory, cognitive theories, socio-technical approaches, and resource-based view theory. The problem of using many different theories is that the results of the theories, brings different innovation puzzle, do not provide a complete frame of the factors that manage innovation properly. However, some theories emphasized the management complexities, while some emphasized on a specific organization or industrial, and others focused on the organizational structure [9].

Moreover, managing innovation for managers is critical since organizational innovation is a risky process associated with a high degree of complexity [45]. However, there are various suggestions on how to manage organizational inno- 
vation; this paper discussed the five dimensions of (Tidd \& Bessant) model to organizational innovation management: strategy, organization, process, linkages and learning [21].

The First dimension is a strategy, which holds that for organizational innovation to be successful there must be a carefully drafted innovation plan. The organization leadership should work with the senior management team on the innovation strategy that can lead to the organization's innovation efforts. In essence, the innovation strategy comprises of a master plan that houses a set of goals and direction required for effective coordination of all innovation initiatives [46]. The second dimension is an organization, which holds that the companies should ensure that their culture and structure promotes innovation [47]. The organization should ensure that a comprehensive innovation institution system is in place. It should comprise of a cross-functional team, which is made of individuals with creative and independent thinking. The third dimension is that of the process. It includes factors such as an organization's geographical coverage, size and flexibility [21]. These aspects should be developed or else an organization will not be able to obtain competitive advantage due to innovation. The fourth dimension is that of linkages. The organization should have effective internal and external linkages to ensure production of innovative output and input [48]. Internal linkages can be in the form of increasing employee interaction, while the external linkages refer to good relationships with other institutions such as research institutions. If these linkages are strong, then an organization is able to reduce the amount it spends on innovation [46]. The last dimension necessary for effective innovation management is learning. An organization should be able to offer new information to its employees and ensure its implementation [49]. New knowledge should be available to bring new ways of thinking and as a milestone to creativity, a solid route to change and innovation [50].

\section{Conclusions}

Organizational innovation is one of the most critical and most complex aspects firms are faced within the modern world we live in. This is because research has depicted that innovation has a substantial effect on an organization's performance and survival. In essence, innovation helps an organization to gain a competitive edge over its rivals and to expand its market share by producing new and unique products for its clients. When an organization is able to achieve this, it will optimize its profitability, an aspect which immensely determines its success rate. In order for managers to ensure effective organizational innovation, they should address the addressing the four domains of strategy, process, supportive organizational context, effective external linkages, and learning. These five domains help an organization to foster the spirit of individual innovation in its employees, which ultimately translate to organizational innovation. The innovation's importance is not only for organization competitiveness but also for social development. 
Many of the scholar findings are still dispersed. However, some empirical studies emphasized on the motivations for innovation, organizational atmosphere, and participative management for innovation as the core elements for managers to be able to lead organizational innovation, while some emphasized on the capability, flexibility, and organizational structures to manage organizational innovation [9]. Additionally, the role of internal organizational forces such as the capacity for learning, the power of organizational transformation, the changes in the technology, interests, and societal value is identified as important factor of organizational innovation [51]. Therefore, future studies should explore more deeply on the internal and external key factors to enhance organizational innovation.

\section{Conflicts of Interest}

The authors declare no conflicts of interest regarding the publication of this paper.

\section{References}

[1] Pfeffer, J. and Sutton, R.I. (2000) The Knowing-Doing Gap: How Smart Companies Turn Knowledge into Action. Harvard Business School Press, Brighton, MA.

[2] Jaskyte, K. (2011) Predictors of Administrative and Technological Innovations in Nonprofit Organizations. Public Administration Review, 71, 77-86. https://doi.org/10.1111/j.1540-6210.2010.02308.x

[3] Dess, G.G. and Picken, J.C. (2000) Changing Roles: Leadership in the 21st Century. Organizational Dynamics, 28, 18-34. https://doi.org/10.1016/S0090-2616(00)88447-8

[4] World Economic Forum (2018) The Future of Jobs Report 2018. Centre for the New Economy and Society.

[5] Myllylä, J. (2019) The Importance of Innovation-What Does It Mean for Businesses and Our Society? https://www.viima.com/blog/importance-of-innovation

[6] Lam, A. (2006) Organizational Innovation. Oxford Handbooks Online. https://doi.org/10.1093/oxfordhb/9780199286805.003.0005

[7] Crossan, M.M. and Apaydin, M. (2009) A Multi-Dimensional Framework of Organizational Innovation: A Systematic Review of the Literature. Journal of Management Studies, 47, 1154-1191. https://doi.org/10.1111/j.1467-6486.2009.00880.x

[8] Noruzy, A., Dalfard, V.M., Azhdari, B., Nazari-Shirkouhi, S. and Rezazadeh, A. (2012) Relations between Transformational Leadership, Organizational Learning, Knowledge Management, Organizational Innovation, and Organizational Performance: An Empirical Investigation of Manufacturing Firms. The International Journal of Advanced Manufacturing Technology, 64, 1073-1085. https://doi.org/10.1007/s00170-012-4038-y

[9] Razavi, S.H. and Attarnezhad, O. (2013) Manegement of Organizational Innovation. International Journal of Business and Social Science, 4, 226-231.

[10] Damanpour, F. and Aravind, D. (2012) Managerial Innovation: Conceptions, Processes, and Antecedents. Management and Organization Review, 8, 423-454. https://doi.org/10.1111/j.1740-8784.2011.00233.x

[11] Thompson, V.A. (1965) Bureaucracy and Innovation. Administrative Science Quar- 
terly, 10, 1-20. https://doi.org/10.2307/2391646

[12] Daft, R.L. (1978) A Dual-Core Model of Organizational Innovation. Academy of Management Journal, 21, 193-210.

[13] Damanpour, F. and Evan, W.M. (1984) Organizational Innovation and Performance: The Problem of "Organizational Lag”. Administrative Science Quarterly, 29, 392-409. https://doi.org/10.2307/2393031

[14] OECD (2005) The Measurement of Scientific and Technological Activities Oslo Manual. Guidelines for Collecting and Interpreting Innovation Data. 3rd Edition, OECD EUROSTAT, Paris. https://doi.org/10.1787/9789264013100-en

[15] Hamel, G. (2006) The Why, What, and How of Management Innovation. Harvard Business Review, 84, 72.

[16] Battisti, G. and Stoneman, P. (2010) How Innovative Are UK Firms? Evidence from the Fourth UK Community Innovation Survey on Synergies between Technological and Organizational Innovations. British Journal of Management, 21, 187-206. https://doi.org/10.1111/j.1467-8551.2009.00629.x

[17] Tavassoli, S. and Karlsson, C. (2016) Innovation Strategies and Firm Performance: Simple or Complex Strategies? Economics of Innovation and New Technology, 25, 631-650. https://doi.org/10.1080/10438599.2015.1108109

[18] Damanpour, F., Walker, R.M. and Avellaneda, C.N. (2009) Combinative Effects of Innovation Types and Organizational Performance: A Longitudinal Study of Service Organizations. Journal of Management Studies, 46, 650-675. https://doi.org/10.1111/j.1467-6486.2008.00814.x

[19] Schumpeter, J. (1934) The Theory of Economic Development: An Inquiry into Profits, Capital, Credit, Interest and Business Cycle. Harvard Economic Studies, 46, 255.

[20] Smith, D. (2009) Exploring Innovation. 2nd Edition, McGraw-Hill Higher Education, London.

[21] Tidd, J. and Bessant, J. (2009) Managing Innovation: Integrating, Technological, Market and Organizational Change. 4th Edition, John Wiley \& Sons Limited, London.

[22] Dewar, R.D. and Dutton, J.E. (1986) The Adoption of Radical and Incremental Innovations: An Empirical Analysis. Management Science, 32, 1422-1433.

[23] Damanpour, F. (1987) The Adoption of Technological, Administrative and Ancillary Innovations: Impact of Organizational Factors. Journal of Management, 13, 675-688. https://doi.org/10.1177/014920638701300408

[24] Damanpour, F. (2017) Organizational Innovation. Oxford Research Encyclopedia of Business and Management. https://doi.org/10.1093/acrefore/9780190224851.013.19

[25] Walker, R. (2007) An Empirical Evaluation of Innovation Types and Organizational and Environmental Characteristics: Towards a Configuration Framework. Journal of Public Administration Research and Theory, 18, 591-615. https://doi.org/10.1093/jopart/mum026

[26] Schilling, M.A. (2010) Strategic Management of Technological Innovation. 3rd Edition, McGraw-Hill/Irwin, New York.

[27] Trott, P. (2008) Innovation Management and New Product Development. 4th Edition, Prentice Hall, London.

[28] Subramanian, A. and Nilakanta, S. (1996) Organizational Innovativeness: Exploring the Relationship Between Organizational Determinants of Innovation, Types of Innovations, and Measures of Organizational Performance. Omega, 24, 631-647. 
https://doi.org/10.1016/S0305-0483(96)00031-X

[29] Knight, K.E. (1967) A Descriptive Model of Intra-Firm Innovation Process. Journal of Management, 40, 478-496. https://doi.org/10.1086/295013

[30] Oke, A., Burke, G. and Myers, A. (2007) Innovation Types and Performance in Growing UK SMEs. International Journal of Operations \& Production Management, 27, 735-753. https://doi.org/10.1108/01443570710756974

[31] Akgün, A.E., Keskin, H. and Byrne, J. (2009) Organizational Emotional Capability, Product and Process Innovation, and Firm Performance: An Empirical Analysis. Journal of Engineering and Technology Management, 26, 103-130. https://doi.org/10.1016/j.jengtecman.2009.06.008

[32] Lin, H.F. (2007) Knowledge Sharing and Firm Innovation Capability: An Empirical Study. International Journal of Manpower, 28, 315-332. https://doi.org/10.1108/01437720710755272

[33] Rowley, J., Bargemen, A. and Sam Brook, S. (2011) Towards an Innovation-Type Mapping Tool. Management Decision, 49, 73-86. https://doi.org/10.1108/00251741111094446

[34] Schmidt, T. and Rammer, C. (2007) Non-Technological and Technological Innovation: Strange Bedfellows? ZEW-Centre for European Economic Research Discussion Paper No. 07-052. https://doi.org/10.2139/ssrn.1010301

[35] Tohidi, H. and Jabbari, M.M. (2012) The Important of Innovation and Its Crucial Role in Growth, Survival and Success of Organizations. Procedia Technology, 1, 535-538. https://doi.org/10.1016/j.protcy.2012.02.116

[36] Martin. (2017) The Innovation Process: Definition, Models, Risks \& Opportunities, Tips. Cleverism. https://www.cleverism.com/innovation-process-definition-models-tips/

[37] Mothe, C. and Nguyen, T. (2010) The Link between Non-Technological Innovations and Technological Innovation. European Journal of Innovation Management, 13, 313-332. https://doi.org/10.1108/14601061011060148

[38] Haned, N., Mothe, C. and Nguyen-Thi, T.U. (2014) Firm Persistence in Technological Innovation: The Relevance of Organizational Innovation. Economics of Innovation and New Technology, 23, 490-516. https://doi.org/10.1080/10438599.2014.895509

[39] Le Bas, C., Mothe, C. and Nguyen-Thi, T.U. (2015) The Differentiated Impacts of Organizational Innovation Practices on Technological Innovation Persistence. European Journal of Innovation Management, 18, 110-127. https://doi.org/10.1108/EJIM-09-2012-0085

[40] Monson, G. (2017) Organizational Culture and Innovation. https://courses.lumenlearning.com/boundless-management/chapter/adapting-and-i nnovating/

[41] Sapprasert, K. and Clausen, T.H. (2012) Organizational Innovation and Its Effects. Industrial and Corporate Change, 21, 1283-1305. https://doi.org/10.1093/icc/dts023

[42] Battisti, G. and Iona, A. (2009) The Intra-Firm Diffusion of Complementary Innovations: Evidence from the Adoption of Management Practices by British Establishments. Research Policy, 38, 1326-1339. https://doi.org/10.1016/j.respol.2009.06.002

[43] Mol, M.J. and Birkinshaw, J. (2009) The Sources of Management Innovation: When Firms Introduce New Management Practices. Journal of Business Research, 62, 1269-1280. https://doi.org/10.1016/j.jbusres.2009.01.001 
[44] Tidd, J. and Bessant, J.R. (2018) Managing Innovation: Integrating Technological, Market and Organizational Change. John Wiley \& Sons, Hoboken, NJ.

[45] Clark, P. (2002) Organizational Innovations. Sage, [Thousand Oaks, CA.

[46] Bay, M. and Çil, U. (2016) How Well Do Companies Manage Innovation? An Analysis on Low-Tech Industries. Journal of Social and Behavioral Sciences, 235, 709-718.

[47] Patrick, M., John, B. and S. Palie, (2005) Developing an Organizational Culture that Facilitates Radical Innovation in a Mature Small to Medium Sized Company: Emergent Findings. SoM Working and Occasional Papers.

[48] Machikita, T. and Ueki, Y. (2017) Innovation in Linked and Non-Linked Firms: Effects of Variety of Linkages in East Asia. Institutions and Economies, 3, 77-102.

[49] Calantone, R.J., Cavusgil, S.T. and Zhao, Y. (2002) Learning Orientation, Firm Innovation Capability, and Firm Performance. Industrial Marketing Management, 31, 515-524. https://doi.org/10.1016/S0019-8501(01)00203-6

[50] Nada, N., Türkyılmaz, A. and El-Badawy, A. (2012) SMEs Innovation Management Framework. International SME Congress, Turgut Özal University, Keçiören, Turkey.

[51] Hage, J.T. (1999) Organizational Innovation and Organizational Change. Annual Review of Sociology, 25, 597-622. https://doi.org/10.1146/annurev.soc.25.1.597 